\title{
Effect of different levels of concentrate supplementation on the performance of Black Bengal goat
}

\author{
MR Ferdous ${ }^{1}$, MJ Khan*1, MA Rashid ${ }^{2}$, M Kamruzzaman ${ }^{1}$ \\ ${ }^{1}$ Department of Animal nutrition, Bangladesh Agricultural University, Mymensingh; ${ }^{2}$ Department of \\ General Animal Science and Animal nutrition, Patuakhali Science and Technology University, Dumki, \\ Patuakhali
}

\begin{abstract}
Fifteen castrated male goats $(12.97 \pm 1.46 \mathrm{Kg})$ aged between 12 and 13 months were used to study the effect of different levels of concentrate supplementation on growth performance and nutrient digestibility in Black Bengal goat under stall feeding. The feeding trial was continued for a period of 75 days where goats were supplied at the rate of $158 \mathrm{~g} \mathrm{DM} / \mathrm{kgW}^{75} /$ day. The animals were assigned into five dietary treatments: A (Only dal grass as sole feed), B (15\% DM from concentrate + $85 \%$ DM from dal grass), C (20\% DM from concentrate $+80 \%$ DM from dal grass), D (25\% DM from concentrate + $75 \%$ DM from dal grass), E (30\% DM from concentrate + 70\% DM from dal grass). Digestibility of all nutrients was gradually higher $(P<0.01)$ from $A$ to $E$. Total live weight gain of goats of group $A$ was statistically lowest $(P<0.01)$ than those of other groups. There was also significant difference $(P<0.01)$ among the treatment groups $E, D, C$ and $B$. Live weight was gradually increase due to gradual increase of concentrate from $B$ to $E$. Nitrogen balance, carcass yield and net profit of treatment group $E$ was highest $(P<0.01)$ then $D, C$ and $B$ than $A$. Green grass do not fulfill the appetite and nutrient requirements as a sole feed. Concentrate supplementation is undoubtedly essential to fulfill the nutrient requirements and concentrate can be supplemented upto $30 \%$ of required DM to obtain the best result.
\end{abstract}

Key words: Black Bengal goat, concentrate supplementation, digestibility, performance Bangladesh Animal Husandry Association. All rights reserved. $\quad$ Bang. J. Anim. Sci. 2011.40 (1-2): 40-45

\section{Introduction}

There are 15.20 million goats in Bangladesh (BBS 2008), of which $98 \%$ is distributed in the rural and $2 \%$ in the urban areas. Small, marginal and landless farmers contributed $75.8 \%$ and medium and large farmers contributed $24.2 \%$ of goat farming in the rural area (Huque 2008). So, goat plays a dominant role in small ruminant production systems and as a means of livelihood in the rural landless farmers. Goats and sheep have been treated as being the neglected species of livestock in Bangladesh, although, they alone represent $58.8 \%$ of the total livestock population (FAO 1999). Goat ranks second in terms of meat, milk and skin production representing about 38, 25 and $28 \%$ among the total contribution of livestock that yield 129 metric tons of meat per year (FAO 1997).

In Bangladesh, about $80 \%$ people are living below poverty level, $90 \%$ people are suffering from malnutrition and becoming the victims of various deficiency diseases. Presently, per capita intake of animal protein is less than $21 \mathrm{~g}$ against the recommended level of $120 \mathrm{~g}$ (Ministry of Fisheries and Livestock 2007). Therefore, goat production could also be an effective means of increasing high quality meat to mitigate the shortage of protein.

Goat plays an important role in generating employment, source of income and capital. Being small in size, they do not require any large management skills and can easily be handled and managed by women and children (Acharya 1992). They are traditionally raised by "povertystricken" village people in a secondary system of grazing on harvested fallow land, along the road and canal sides without any supplementation. For the poor farmers who are unable to maintain large ruminants, goat justifies its designation as "the poor man's cow".

Some findings reflected that only grazing might not be sufficient for weight gain of goats (Kochapakdee et al. 1994; Mahjan et al. 1976). If scavenging goats can be supplemented with minimum amount of concentrate, the level of production may be increased at the minimum cost. With the growing human population and increasing demand for cereal food, the lands used for natural grazing of goats are reducing day by day. So, farmers are now trying to adapt and rear goat under intensive management system. Therefore, appropriate feeding technique 
is needed for goat to be reared under intensive condition. To achieve the goal, the productivity of goat may be increased through nutritional manipulation either by concentrate feeding (Pathasarathy, 1986) or supplying good quality forages (Muri and Jordan 1991). Energy and protein concentrations of the diet play a significant role on growth of goats (NRC, 1981). Louca and Hancock (1977) reported that growth rate of kids increased with increasing protein content of the diet. However, reports on the nutrient requirements are scanty and very little information is available particularly on the contribution of dietary protein to the performance of Black Bengal goats under Bangladesh condition.

Therefore, the present experiment was undertaken to investigate the effects of different levels of concentrates on nutrient intake, digestibility, growth and carcass yield in Black Bengal goats under intensive system of rearing.

\section{Materials and Methods}

The study was conducted at the Animal Nutrition Field Laboratory, Bangladesh Agricultural University, Mymensingh for a period of 75 days between February and May 2009. Ambient temperature during the experimental period varied from 21.52 to $32.55^{\circ} \mathrm{C}$ with an average relative humidity of $80.72 \%$ (Weather Yard, 2009, BAU station) was recorded.

\section{Experimental Animals and Management}

Fifteen (15) castrated male Black Bengal goats aged between 12 and 13 months weighing on an average of $12.97 \pm 1.46 \mathrm{~kg}$ were used for the experiment. The animals were allowed 10 days to adapt with the experimental conditions and experimental feed prior to the commencement of the study. All the goats were ear tagged; feces were examined for parasitic infestation and dewormed with an antihelmentic drug (Livamizol, $250 \mathrm{mg}$ ). Following adaptation, goats were housed in individual pens subjected to natural ventilation and sun light. All animals were reared under same management condition. All goats were housed in a tin shed having iron-slatted floor raised above the ground level to keep them comfortable. Separate feeders were used for roughage and concentrate for each goat. Experimental animals were examined routinely to identify any health problems. Feeder and waterer were cleaned every morning before supplying the feeds.

\section{Experimental Diets}

The goats were assigned at random to five treatment groups (A-E) with three goats in each group. The animals of the dietary group A received only Dal grass (Hymenachne amplexicaulis) and the goats of group $\mathrm{B}$ to $\mathrm{E}$ received concentrate mixture 15, 20, 25 and 30\% of required dry matter respectively and rest from Dal grass. Each diet was supplied to the respective group @ $158 \mathrm{~g}$ DM per $\mathrm{kgW}^{75}$. Dal grass was fed as roughage and concentrate feed comprised of maize $(50 \%)$, wheat bran $(19 \%)$, mustard oil cake $(20 \%)$, soybean meal $(5 \%)$, bone meal (5\%) and salt (1\%). The concentrate mixture contained $89.2 \% \mathrm{DM}, 15.6 \% \mathrm{CP}$ and 12.6 MJ ME/kg DM. Dal grass was collected in every morning and evening followed by cleaning, chopping and supplied to the animals. The concentrate mixture and green grass were offered individually in plastic pans and wooden basket respectively. The roughage and concentrate portions of the diets were fed separately. About $50 \%$ of the diet (roughage and concentrate) were provided at $7.30 \mathrm{am}$ and the remaining at $4.00 \mathrm{pm}$. Fresh drinking water was made available ad libitum to all goats at all times.

\section{Measurement of live weight gain}

The initial live weight of each goat was taken at the beginning of the experiment for two consecutive days before offering feed at morning and the mean weight of individual animals were recorded as initial weight. Thereafter, animals were weighed individually in every 7 days interval throughout the experimental period. Final live weight of each animal was taken as an average weight of two consecutive days after completion of 75 days trial.

\section{Digestibility Measurement}

A conventional digestibility trial was conducted at the end of the growth trial for 7 days to assess the utilization of dietary nutrient by the goats. Feed refusals and feces voided by each goat during 24 hours were collected and weighed. All possible precautions were taken such as goat was kept in individual metabolic crates and feces was collected carefully from the net of metabolic crates to avoid mixing with urine.

\section{Carcass Yield}

The animals were weighed individually and slaughtered. The slaughtered goats were allowed 


\section{Concentrate supplementation on goat performance}

to bleed properly usually for 10 minutes. The carcass was hoisted from its hock at a convenient height. The head was then removed at its atlanto-occipital articulation followed by flaying and evisceration. Feet below the carpals (knee bones) in the forelegs and tarsals in the hind legs were also removed. After finishing the above process the carcass weight were taken individually. Then dressing percentage was calculated from the carcass weight divided by the live weight then multiplying by 100 .

\section{Chemical analysis}

Respective samples of feed, feces and leftover were subjected to chemical analysis for the determination of dry matter (DM), organic matter $(\mathrm{OM})$, crude protein $(\mathrm{CP})$, crude fibre $(\mathrm{CF})$, ether extract (EE) and nitrogen free extract (NFE) following the methods of AOAC (2004).

\section{Statistical analysis of the data}

The data were analyzed using the "MSTATC" statistical program to compute analysis of variance (ANOVA) in a completely randomized design (CRD) and the mean values with standard error deviation (SED) were recorded. Duncan's Multiple Range Test (DMRT) was also done to compare the treatment means for different parameters.

\section{Results and Discussion}

\section{Digestibility}

The DM, CP, CF, EE, NFE and OM digestibility (\%) for $B, C, D$ and $E$ diets were significantly higher $(P<0.01)$ than diet of $A$ (Table 1$)$. There was also significant variation $(P<0.01)$ among $B$, $C, D$ and $E$ gradually due to gradual increase of concentrate. This result of CP digestibility agreed with the result of Omar (2002) in which he stated that CP digestibility of $20 \%$ sesame oil cake (83.0) was significantly $(P<0.05)$ higher than $10 \%$ sesame oil cake (79.7) feed. Soto-Navarro et al. (2005) reported no significant variation in nitrogen digestibility from different levels of SBM supplementation. Higher level of protein from SBM helped increase digestibility of protein.

\section{Growth performance}

The effects of concentrate supplementation on growth performance are shown in Table 2 and
Figure 1. The total live weight gain of goats belonged that group $E$ was statistically higher $(P<0.01)$ than group $A$ and $B$. Though group $B$ showed higher live weight gain than group $A$ but there was no significant difference among B, C and D as well as C, D and E. Previous studies (Shahjalal et al. 1992) indicated that sources of nitrogen supplementation had effect on weight gain of Angora goats. The average live weight gain per day in kids received the high protein diet $(16 \% \mathrm{CP})$ was higher $(62.4 \mathrm{vs} .45 .4 \mathrm{~g} / \mathrm{d})$ than those fed the low protein diet $(10 \% \mathrm{CP})$ up to weaning (Kabir et al. 2002). The higher level of concentrate supplement increased daily live weight gain of kids (Bhuiyan et al. 1996).

However, there are also evidences that growth rate increased linearly as the level of protein increased in the diet (Bishwas, 1997; Lu and Potchoiba 1990). Feed conversion efficiency (LWG/DMI) in group $E$ was higher $(P<0.01)$ than other groups. There was no significant difference among $B, C$ and $D$ and $B$ and $A$ but $C$ and $D$ differed from $A$. In contrast, DM intake, weight gain and feed efficiency (ADG/DMI) were mostly similar among goats receiving different levels of $\mathrm{CP}$ in the diet (Prieto et al. 2000). Bishwas (1997) also showed that high protein diet did not significantly improve conversion efficiency of DM and ME. Protein conversion efficiency (PCE) of group $B, C, D$ and $E$ was statistically higher $(P<0.05)$ than group $A$. Energetic efficiency was highest $(P<0.05)$ in group $E$ then $D$ followed by $C$ and $B$ than $A$. The difference of different parameters (Total LWG, FCE, PCF and energetic efficiency) among different treatment groups ( $A$, $B, C, D$ and $E$ ) might be due to supplementation of different level of concentrate particularly CP and ME.

\section{Nitrogen Balance}

All the animals used in the present experiment showed positive nitrogen balance. It can be observed from Table 2 that $\mathrm{N}$ balance of goats fed diet $B, C, D$ and $E$ showed significantly higher $(P<0.01)$ values than diet $A$. Though there was no significant difference among $E, D$ and $C$ or $D$, $\mathrm{C}$ and $\mathrm{B}$ but $\mathrm{E}$ showed highest $\mathrm{N}$ balance. These results indicate that an increase in concentrate supplementation showed significantly higher $\mathrm{N}$ balance. 
Ferdous et al. (2011) Bang. J. Anim. Sci. 40 (1\& 2): 40-45

Table 1. Apparent digestibility of different diets $(\mathrm{g} / 100 \mathrm{~g})$

\begin{tabular}{|c|c|c|c|c|c|c|c|}
\hline \multirow{2}{*}{ Item } & \multicolumn{5}{|c|}{ Dietary treatments } & \multirow{2}{*}{ SED } & \multirow{2}{*}{ Sig. } \\
\hline & A & $B$ & C & D & $E$ & & \\
\hline$\overline{D M}$ & $50.49^{e}$ & $54.61^{d}$ & $58.48^{\mathrm{C}}$ & $64.26^{b}$ & $66.55^{a}$ & 1.61 & $* *$ \\
\hline $\mathrm{CP}$ & $47.50^{\mathrm{e}}$ & $56.84^{d}$ & $60.67^{c}$ & $63.69^{b}$ & $66.80^{a}$ & 4.01 & $* *$ \\
\hline $\mathrm{CF}$ & $50.23^{e}$ & $52.71^{d}$ & $57.22^{c}$ & $66.97^{b}$ & $69.46^{\mathrm{a}}$ & 2.11 & $* *$ \\
\hline $\mathrm{EE}$ & $49.17^{e}$ & $54.06^{d}$ & $59.23^{c}$ & $61.82^{b}$ & $65.31^{a}$ & 1.60 & $* *$ \\
\hline NFE & $49.63^{\mathrm{e}}$ & $55.55^{d}$ & $59.77^{c}$ & $65.09^{b}$ & $67.44^{\mathrm{a}}$ & 1.79 & $* *$ \\
\hline OM & $50.99^{e}$ & $60.97^{d}$ & $63.44^{c}$ & $66.16^{b}$ & $70.96^{a}$ & 1.83 & $* *$ \\
\hline
\end{tabular}

Figures with different superscript in the same column differ significantly; ${ }^{* *}$, significant at $1 \%$ level of probability; SED, standard errors of deviation

Table 2. Growth performance of Black Bengal goats fed different levels of concentrate supplement

\begin{tabular}{|c|c|c|c|c|c|c|c|}
\hline \multirow{2}{*}{ Parameters } & \multicolumn{5}{|c|}{ Dietary treatments } & \multirow{2}{*}{ SED } & \multirow{2}{*}{ Sig. } \\
\hline & A & B & $\mathrm{C}$ & $\mathrm{D}$ & $E$ & & \\
\hline Initial live wt & 12.99 & 13.05 & 12.87 & 12.94 & 12.99 & 0.39 & NS \\
\hline Final live wt $(\mathrm{kg})$ & 14.06 & 15.58 & 15.80 & 16.14 & 16.90 & 0.50 & NS \\
\hline Total live wt. gain $(\mathrm{kg})$ & $1.07^{\mathrm{C}}$ & $2.53^{b}$ & $2.93^{\mathrm{ab}}$ & $3.20^{\mathrm{ab}}$ & $3.93^{\mathrm{a}}$ & 0.31 & $* *$ \\
\hline FCE (IWG/DMI) & $0.04^{c}$ & $0.07^{\mathrm{bc}}$ & $0.08^{b}$ & $0.08^{\mathrm{b}}$ & $0.09^{a}$ & 0.00 & $* *$ \\
\hline PCE (CPI/LWG) & $2.18^{\mathrm{a}}$ & $1.51^{\mathrm{cb}}$ & $1.33^{\mathrm{bc}}$ & $1.30^{\mathrm{b}}$ & $1.16^{\mathrm{b}}$ & 0.13 & $*$ \\
\hline Energetic efficiency (MEI/LWG) & $0.22^{\mathrm{a}}$ & $0.15^{\mathrm{b}}$ & $0.12^{c}$ & $0.12^{c}$ & $0.11^{\mathrm{d}}$ & 0.01 & $*$ \\
\hline $\mathrm{N}$ balance $(\mathrm{g} / \mathrm{d})$ & $3.14^{\mathrm{C}}$ & $5.98^{\mathrm{b}}$ & $6.48^{\mathrm{ab}}$ & $6.80^{\mathrm{ab}}$ & $7.82^{\mathrm{a}}$ & 0.491 & $* *$ \\
\hline
\end{tabular}

Figures with different superscript in the same column differ significantly; $*$ and **, significant at $5 \%$ and $1 \%$ level of probability, respectively; NS, not significant; SED, standard errors of deviation

\section{Carcass characteristics}

The dressing percentages of concentrate supplemented groups ( $B, C, D$ and $E$ ) were higher than group $A$, fed only dal grass. The dressing percentage was gradually increased due to gradual increase of concentrate supplementation (Table 3). The dressing percentage of present study was higher than the value for Black Bengal goat and cross bred (41.48\% to $43.73 \%)$ observed by Abedin et al. (2005), Moniruzzaman et al. (2002) and Das et al. (2005). However, a lower dressing percent and age of Black Bengal goats $(38.61 \%)$ was also reported by Singh et al. (1986) in Indian Black Bengal goat. Chowdhury and Faruque (2004b) reported dressing percent of Black Bengal goat between 181 and 365 days of age was $46.4 \%$. Devendra and Owen (1983) and Verma et al. (2004) reported the value $48.10 \%-52.15 \%$ for Indian pure Black Bengal breed. These two values agreed with the present findings. The variation in dressing percentage of Black Bengal goats observed by different investigators might be due to the variation in age, body condition and nutritional status of the slaughtered animals.

\section{Economics study of the experiment}

The feed cost of rearing animals was calculated based on the market price of feed ingredients during the trail period. The Price of dal grass was taken as Tk 0.5 per $\mathrm{kg}$. It reveals from Table 4 that the total feed cost per animal of group $E$ was statistically higher $(p<0.01)$ than $B, C, D$ and $A$. But the cost for $B, C$ and $D$ was statistically similar and differed from $A$.

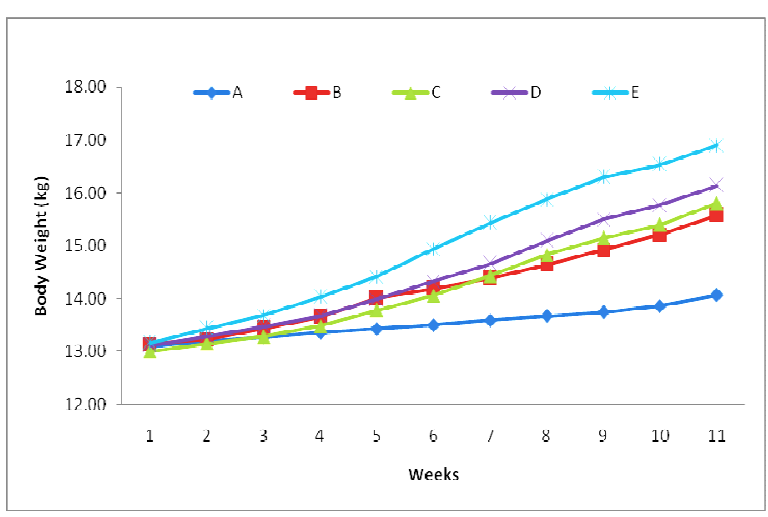

Figure 1. Cumulative body weight of different groups of goats

Total rearing cost also similar to feed cost accept group $B$. Total cost of B was lower than group C and $D$. Total meat yield was highest $(P<0.01)$ in group $E$ than other groups. Net profit was highest $(P<0.01)$ in group $E(+134.25)$ than that of group $B$ and $A$. There was no statistical difference among group C, D and E or group B, C and D. Group A showed negative balance $(-115.25)$. 
Concentrate supplementation on goat performance

Table 3. Cost analysis of different treatment groups per goat by 75 days

\begin{tabular}{|c|c|c|c|c|c|c|c|}
\hline \multirow{2}{*}{ Parameters } & \multicolumn{5}{|c|}{ Dietary treatment } & \multirow{2}{*}{ SED } & \multirow{2}{*}{ Sig. leve } \\
\hline & A & $B$ & C & $\mathrm{D}$ & $E$ & & \\
\hline Total feed cost & $83.25^{c}$ & $235.5^{b}$ & $291.75^{b}$ & $337.25^{\mathrm{b}}$ & $414.75^{a}$ & & $* *$ \\
\hline$*$ Other costs & 200 & 200 & 200 & 200 & 200 & 0.00 & - \\
\hline Total cost of rearing & $283.25^{\mathrm{d}}$ & $435.25^{c}$ & $491.25^{b}$ & $537.25^{b}$ & $614.75^{\mathrm{a}}$ & 33.82 & $* *$ \\
\hline weight gain $(\mathrm{kg})$ & $1.07^{\mathrm{C}}$ & $2.53^{b}$ & $2.93^{\mathrm{ab}}$ & $3.20^{\mathrm{ab}}$ & $3.93^{\mathrm{a}}$ & 0.31 & $* *$ \\
\hline Dressing \% & $45.22^{c}$ & $51.45^{\mathrm{b}}$ & $52.05^{\mathrm{ab}}$ & $53.65^{\mathrm{ab}}$ & $54.73^{a}$ & 0.99 & $* *$ \\
\hline Total meat yield & $0.484^{c}$ & $1.30^{\mathrm{b}}$ & $1.53^{\mathrm{ab}}$ & $1.72^{\mathrm{ab}}$ & $2.15^{\mathrm{a}}$ & 0.18 & $* *$ \\
\hline Price of meat (@ 350Tk/kg) & $168.0^{c}$ & $455^{b}$ & $535.16^{\mathrm{ab}}$ & $600.83^{\mathrm{ab}}$ & $749^{a}$ & 62.89 & $* *$ \\
\hline Profit/loss (Tk/animal) & $-115.25^{c}$ & $+19.75^{b}$ & $+43.91^{\mathrm{ab}}$ & $+63.58^{\mathrm{ab}}$ & $+134.25^{\mathrm{a}}$ & 27.24 & $* *$ \\
\hline
\end{tabular}

*Other cost, Labour cost, plastic bottle etc.; Means with different superscripts in the same column differed significantly; SED, standard error deviation; **, $p<0.01 ;+$, profit; -, loss

\section{Conclusion}

Feeding of goats through supplying of green grass do not fulfill the appetite and nutrient requirements. Concentrate supplementation is undoubtedly essential to fulfill the nutrient requirements. Supplementation of concentrate mixture with $15.60 \%$ crude protein at the rate of $30 \%$ of total required dry matter per $100 \mathrm{~kg}$ body weight is suggested for optimizing growth performance of Black Bengal goat under stallfeeding system in Bangladesh.

\section{References}

Abedin SMA, Alam MR and Faruque MO (2005). Comparative carcass characteristics of ruminant species in Bangladesh. J. Bang. Agric. Univ. 3: 243-249.

Acharya RM (1992). Goat Genetic Resources and their Management. Research in goats, Indian Experience. Central Institute for Research on Goats, Makhdoom, Mathura. P. $1-21$.

AOAC (2004). Official Methods of Analysis (13 ${ }^{\text {th }}$ edition). Association of Official Analytical Chemists. Washington, D.C.

BBS (2008). Bangladesh Bureau of Statistics. Statistical Pocket Book of Bangladesh. Statistics Division, Ministry of Planning, Dhaka Bangladesh.

Bhuyian R, Buruah KK and Das PC (1996). Growth response and characteristics of crossbred kids fed ration having different concentrate to roughage rations. Ind. J. Anim. Nutr. 13: 167-169.

Bishwas MAA (1997). Effect of dietary protein concentration and feeding level on growth and carcass characteristics of Black Bengal goats. M.S. Thesis, Department of Animal
Nutrition, Bangladesh Agricultural University, Mymensingh.

Chowdhury SA and Faruque S (2004b). Meat production characteristics of Black Bengal goat. Asian-Aust. J. Anim. Sci.17: 848856.

Das $S$, Husain SS, Hoque MA and Amin MR (2005). Association between body measurements and carcass characteristics of goats. Bang. J. Anim. Sci. 30: 85-91.

Devendra C and Owen JE (1983). Quantitative and qualitative aspects of meat production from goats. World Anim. Rev. 47: 19 - 29.

FAO (1997). Food and Agricultural Organization of the United Nations. Production Year Book, FAO, Rome, Italy. 51: 189- 228.

FAO (1999). Food and Agricultural Organization of the United Nations. Production Year Book, FAO, Rome, Italy. 5: $210-213$.

Huque KS (2008). A seminar on livestock and poultry production and feed availability in Bangladesh, Bang. Lives. Res. Ins. (BLRI), Saver, Dhaka.

Kabir F, Sahjalal M, Chowdhury SA, Alam J and Islam MR (2002). Effect of protein supplementation to grazing on growth and reproductive performance in female goats and sheep. Pak. J. Biol. Sci. 5: 719-721.

Kochapakdee S, Pralomkam S, Saitanoo A and Norton BW (1994). Productivity of female goat grazing newly established pasture with varying levels of supplementary feeding. Asian-Aust. J. Anim. Sci. 7: 289-293.

Louca A and Hancock J (1977). Genotype and environmental interactions for post weaning Growth in the Damascus breed of goat. J. Anim. Sci. 44: 927- 1759. 
Lu CD and Potchoiba MJ (1990). Feed intake and weight gain of growing goats fed diets of Various energy and protein levels. J. Anim. Sci. 68: 1751-1759.

MAAF (1984). Energy allowance and feeding systems for ruminant. Ministry of Agricultural, Fisheries and Food Technical Bulletin No. 433 HMSO, London.

Mahjan JM, Chauhan DS and Tipmar VP (1976). Effects of supplementary feeding to grazing on growth and wool production in sheep. Ind. J. Anim. Res. 10: 90-92.

Moniruzzaman $M$, Hashen MA, Akther $S$ and Hossain MM (2002). Effect of different feeding system on carcass and noncarcass parameters of Black Bengal goats. Asina-Aust. J. Anim. Sci. 5: 61-65.

Muri J and Jordan C (1991). Preliminary data on growth of goats raised in an improved pasture system in Mozambique. In: Proc. $3^{\text {rd }}$ Int. Sym. Nutr. Herbivores. The Malaysian Soc. Anim. Prod. P. 65-71.

NRC (1981). Nutrient requirements of domestic animals, No. 15. Nutrient Requirements of Goats: Angora, dairy and meat goats in temperate and tropical countries. National Academy Press, Washington, D C.

Omar JMA (2002). Effect of feeding different levels of sesame oil cake on performance and digestibility of Awassi lambs. Small Rumin. Res. 46: 187-190

Weather Yard (2009). Bangladesh Agricultural University Station, Mymensingh.
Pathasarathy M (1986). Effect of feeding varying level of Khejri (Prosopis cinerari) leaves and concentrates on the performance of weaner kids. Ind. J. Anim. Nutr. 3: 249253.

Prieto L, Goetsch AL, Kalieva V, Cameron M, Puchala R, Sahlu T, Dawson L, Coleman SW (2000). Effects of dietary protein concentration on post weaning growth Boer crossbred and Spanish goat wethers. J. Anim. Sci. 78: 2275-2281.

Shahjalal M, Galbraith H and Topps JH (1992). The effect of changing in dietary protein and energy on growth, body composition, mohair fibre characteristics of British Angora goats. Anim. Prod. 54: 405-412.

Singh DK, R Singh, BB Singh, CSP Singh and hR Misra. (1986). Studies on effect of Genetic group and age at slaughter or same carcass traits of goats. Ind. Vet. J. 62: 782-787.

Soto-Navarro SA, Goetsch AL, Sahlu T, Puchala R and Dawson LJ (2005). Effect of ruminally degraded nitrogen source and level in a high concentrate diet on site of digestion in Boer- Spanish weather. Institute for Goat Research, Langston University, Langston.

Verma AK, Sasty VRB and Agarwal DK (2004).Chevon characteristics of goats fed diets with water washed neem (Azedirachta indica) seed karnel cake. Small Rumin. Res. 19: 55-61. 